\title{
Radiocarbon
}

1969

\section{ANU RADIOCARBON DATE LIST III}

\section{H. A. POLACH*, J. CHAPPELL**, and J. F. LOVERING† \\ Australian National University, Canberra, Australia}

The present list comprises only research projects undertaken by the laboratory on the validity of radiocarbon dating of soil, shell, coral and very old samples, all in presence of suspected contamination. All measurements were performed on a Beckman LS-200 liquid scintillation spectrometer (Radiocarbon, 1968, v. 10, p. 179-199). The chemical treatment of samples is given within the text of each section.

Significant modifications to our counting procedures have occurred. The liquid scintillation unit has been set up for optimal performance and is insensitive to chemical quenching or electronically induced count rate variations so that the degree of stability exceeds by a factor of ca. 100 the fluctuations observed under normal operations (Polach, 1969).

A technique of automatic cycling of 10 vials at $20 \mathrm{~min}$. intervals, accumulating a $1000 \mathrm{~min}$. count for each vial over a period of 1 week, has also been established. It consists of placing within the automatic changer 7 sample vials, 2 sealed background vials, and 1 sealed "Hot" $\mathrm{C}^{11}$ standard, giving an equivalent $11,500 \mathrm{~min}$. total time determination for each weekly cycle. It replaces the generally practiced low-count-rate, low-background detection technique of alternating 1 to 3 day-long determinations of background, "modern" standard and unknown sample. The inherent weakness of the normal alternating method is the need to extrapolate background and "modern" count rates over the extended period during which a sample is actually counted. The cycling method provides quasi-simultaneous background and "modern" count-rate checks, improves stability and long term reproducibility and almost trebles output.

A new vial design has been developed to minimize the solvent vapor losses of the commercially available counting vials.

A high level of automation of data-output procedures is being achieved by using modern data-processing facilities. The raw count data are recorded on tape and handled by a series of comprehensive computer programs. The computer creates a full sequential file of all operations, assesses background stability and validity of "modern" value determination based on equipment performance tests, statistically analyzes all data and calculates all results. Details of the cycling procedures, new vial design, computer programs and the calculation of radiocarbon ages are

* Dept. of Geophysics and Geochemistry, Dept. of Anthropology and Sociology

** Dept. of Geography, School of General Studies

$\dagger$ Dept. of Geophysics and Geochemistry 
reported by Polach (1969). A detailed account of the statistical analyses and error term calculations as well as computer program flow charts are given by Polach and Havas (Automation and computerization of radiocarbon age determinations: $\mathrm{ms}$. in preparation).

Ages in this date list are reported relative to A.D. 1950 on the basis of Libby half-life. As all samples are of geologic significance, B.C. and A.D. ages have not been calculated. We also propose to report $\delta \mathrm{C}^{14}$ or $\Delta$ values (Radiocarbon, 1961, v. 3, p. 176-204 and editorial statement) to enable statistical evaluation of the ages of samples which have been reported as Greater than or Modern ages (Polach, 1969). We shall also apply $\delta \mathrm{C}^{13}$ corrections based on either mass-spectrometric $\mathrm{C}^{13} / \mathrm{C}^{12}$ ratio determinations on samples or on the best available estimate of their group mean values based on carbon-isotopic distribution in nature as established by Craig (1954) and since confirmed by many hundreds of measurements. All $\delta$ or $\Delta$ values are reported as parts per thousand $(\%)$ deviation from standard; $\delta \mathrm{C}^{14}$ as $\%$ enrichment $(+)$ or depletion (-) w.r.t. 0.95 Oxalic N.B.S. Modern reference standard; and $\delta \mathrm{C}^{13}$ w.r.t. PD Belemmite Chicago limestone standard (Craig, 1957).

\section{ACKNOWLEDGMENTS}

We wish to acknowledge the significant contribution to the management of this laboratory made by J. Golson, Dept. of Anthropology and Sociology (Prehistory), A.N.U. and Dr. J. J. Stipp, Inst. of Marine Sciences, Miami, Florida, U.S.A., who was the first to suggest to us the cycling operations and whose early cooperation with the laboratory was well appreciated. J. Chappell, Dept. of Geography, School of General Studies, A.N.U. operated the laboratory during a six weeks' absence overseas of H.A.P. J. Chappell not only prepared his own samples and calculated and cross-validated his own results but contributed ideas on the evolution of the new vial and cycling procedures. G. Havas, then Research Assistant, Dept. of Geography, Research School of Pacific Studies, A.N.U., wrote and tested the computer programs. We also wish to thank T. A. Rafter, Dir., Inst. Nuclear Sciences, New Zealand for allowing one of us (H.A.P.) to run $125 \mathrm{C}^{13} / \mathrm{C}^{12}$ ratio determinations within the Mass-Spectrometry Section of the Institute under the direction of Dr. J. Hulston to whom H.A.P. is particularly indebted.

\section{SAMPLE DESCRIPTIONS}

\section{GEOLOGIC SAMPLES}

\section{A. Australia, Periglacial Deposits}

This study forms part of investigations into periglacial deposits in SE Australia (Costin, A. B., Polach, H. A., and Wimbush, D. J., Slope deposits in the Kosciusko area, Australia: ms. in preparation). Two of the objectives are to determine the time or times of periglaciation when the deposits accumulated, and to develop methods of concentration and preparation for dating appropriate to soil materials in which a variety of soil-organic fractions occur together. Selection of sampling sites by 
Costin was based on the requirement of the dating laboratory to obtain control ages on carbonized wood believed by pedologists, on the basis of soil-fabric analysis, to have been incorporated in the periglacial deposits at the time of accumulation.

Each sample was examined under low-power stereo-microscope in order to pick out visible contaminants (rootlets, etc.). The carbonized wood (small spicules up to pieces a few $\mathrm{mm}$ in diameter) was then assembled as control fraction "A". The "soil residue", now free of visible rootlets but still containing flecks of carbonized wood too small to be picked out, was proportioned into two parts. Part I was treated with $\mathrm{HCl}(\mathrm{pH} 3)$, boiled, and macerated by vigorous agitation with an electric stirrer for an hour. The sample which settled out was evaporated to dryness. The surface crust, relatively rich in clay and organic soil, was easily separated, to provide fraction " $\mathrm{D}$ " for dating; the remaining carbon-poor silicate sands and stone fragments were discarded. Part II of the "soil residue" was treated with $2 \% \mathrm{NaOH}$, and the soluble "humic acids" were separated from the insoluble residue by decantation and filtration and recovered for dating as fraction " $\mathrm{B}$ " by acid re-precipitation. The washed $\mathrm{NaOH}$-insoluble residue was acidified and dated as fraction "C", after the settling-enrichment as practised for fraction " $D$ ". The samples were collected by A. B. Costin, J. F. Lovering, and H. A. Polach in 1967 and recollected by A. B. Costin in 1968.

\section{Munyang series, Kosciusko}

ANU-143 Al.

$$
\Delta=-978.4 \pm 4.8 \quad \text { Est. } \delta C^{13}=-24.0 \pm 2.0 \%
$$

Carbonized wood specks within chocolate brown soil near base of slope mantle deposits. Munyang Power Sta. $\left(36^{\circ} 21^{\prime} \mathrm{S}\right.$ Lat, $148^{\circ} 24^{\prime} \mathrm{E}$ Long). Benzene dilution, 4440 min. count.

ANU-143 A2.

$$
\Delta=-977.5 \pm 4.3 \quad \text { Est. } \delta C^{13}=-24.0 \pm 2.0 \% 0
$$

Recollection of ANU-143 Al. Benzene dilution, 2020 min. count.

ANU-143 B.

$$
\Delta=-981.5 \pm 3.4 \quad \text { Est. } \delta C^{13}=-24.0 \pm 2.0 \%
$$

$\mathrm{NaOH}$-soluble fraction of "soil residue" after extraction of charcoal ANU-143 A, and microscopically visible contaminants. Benzene, 1000 min. count.

ANU-143 C.

$18,540 \pm 890$

$$
\Delta=-900.5 \pm 10.5 \quad \text { Est. } \delta C^{13}=-24.0 \pm 2.0 \%
$$

$\mathrm{NaOH}$-insoluble fraction. Benzene, $2000 \mathrm{~min}$. count. 
ANU-143 D.

"Soil residue" after charcoal extraction. Benzene, $960 \mathrm{~min}$. count.

ANU-144 A.

\section{$\mathbf{2 6 , 5 0 0}$}

$$
\Delta=-963.1 \pm 10.4 \quad \delta C^{13}=-25.1 \pm 0.2 \%
$$

Carbonized wood specks contained in grayish lens of soil within and above chocolate brown soil, from which ANU-143 was derived, at base of slope mantle deposits. Munyang Power Sta. Benzene dilution, 2620 min. count.

ANU-144 B.

$$
\Delta=-952.6 \pm 3.6 \quad \text { Est. } \delta C^{13}=-24.0 \pm 2.0 \%
$$

$\mathrm{NaOH}$-soluble fraction. Benzene dilution, $2020 \mathrm{~min}$. count.

ANU-144 C.

20,300

$\mathrm{NaOH}$-insoluble fraction. Benzene dilution, $3060 \mathrm{~min}$. count.

ANU-144 D.

$18,550 \pm 520$

$$
\Delta=-900.5 \pm 6.3 \quad \text { Est. } \delta C^{13}=-24.0 \pm 2.0 \%
$$

"Soil residue" after charcoal extraction. Benzene dilution, $980 \mathrm{~min}$. count.

General Comment (H.A.P.): "control ages" of carbonized wood in 2 samples, ANU-143 A1 and A2 indicate ca. 31,000 B.P. as start of the periglaciation that produced widespread slope deposits in this area. Substantially similar age for ANU-143 B indicates that the buried humic soil in which carbonized wood occurs has not been contaminated by down-washed humus or by exposure. On the other hand, dates of ca. 20,000 B.P. for ANU-143 C and D indicate that there has been substantial contamination by roots and rootlets of which fragments are now too small or partially decomposed to be visible and effectively hand-separated. Clearly, dating of whole soil would give erroneously young age for commencement of periglacial instability.

\section{Island Bend series, Kosciusko}

ANU-145 A.

Carbonized wood specks within reddish brown soil near base of slope mantle deposits. Island Bend (36 $16^{\circ} 9^{\prime} \mathrm{S}$ Lat, $148^{\circ} 29^{\prime} \mathrm{E}$ Long). Benzene dilution, 3960 min. count. Comment (H.A.P.): because of small amount of carbonized wood capable of being hand-picked from sample, age of ANU-145 A gives only a broad indication of when periglacial conditions began. However, the result is not significantly different from age of the Munyang samples (ANU-143 and 144). 
ANU-145 B.

$22,190 \pm 600$

$$
\Delta=-937.0 \pm 4.6 \quad \text { Est. } \delta C^{13}=-24.0 \pm 2.0 \%
$$

$\mathrm{NaOH}$-soluble fraction. Benzene dilution, $3660 \mathrm{~min}$. count.

ANU-145 C.

$\Delta=-890.1 \pm 20.4 \quad$ Est. $\delta C^{13}=-24.0 \pm 2.0 \%$ o

$\mathrm{NaOH}$-insoluble fraction. Benzene dilution, $3040 \mathrm{~min}$. count.

ANU-145 D.

$14,430 \pm 500$

$\Delta=-834.0 \pm 10.3 \quad$ Est. $\delta C^{13}=-24.0 \pm 2.0 \%$ count.

"Soil residue" after charcoal extraction. Benzene dilution, $2600 \mathrm{~min}$.

\section{Geehi series, Kosciusko}

ANU-146 A.

$\Delta=-985.0 \pm 3.6 \quad$ Est. $\delta C^{13}=-24.0 \pm 2.0 \%$

Carbonized specks within brown soil near base of slope mantle deposits. Near Geehi R. (36 $16^{\prime}$ S Lat, $148^{\circ} 20^{\prime}$ E Long). Benzene, 980 min. count.

ANU-146 B.

$$
\Delta=-955.3 \pm 3.2 \quad \text { Est. } \delta C^{13}=-24.0 \pm 2.0 \%
$$

$\mathrm{NaOH}$-soluble fraction. Benzene dilution, $1980 \mathrm{~min}$. count.

ANU-146 C.

$\mathbf{2 5 , 3 6 0} \pm \mathbf{5 8 0}$

$$
\Delta=-957.6 \pm 3.0 \quad \text { Est. } \delta C^{13}=-24.0 \pm 2.0 \%
$$

$\mathrm{NaOH}$-insoluble fraction. Benzene dilution, $2240 \mathrm{~min}$. count.

ANU-146 D.

$$
19,980 \pm 370
$$

$$
\Delta=-916.0 \pm 3.7 \quad \text { Est. } \delta C^{13}=-24.0 \pm 2.0 \%
$$

"Soil residue" after charcoal extraction. Benzene, 1020 min. count. General Comment (H.A.P.): control age of carbonized wood, ANU-146 A, gives ca. 34,000 B.P. for the beginning of slope instability at Geehi site (cf. Munyang). Younger age of ANU-146 B and C indicates that, in contrast with the Munyang material, contamination of this buried soil by clown-washed humus or exposure has occurred. Rootlet contamination is shown by still younger age of ANU-146 D.

General Comment on periglacial deposits, Kosciusko (A.B.C.): similarity of "control dates" of Munyang, Island Bend, and Geehi samples indicates that a widespread, severe periglacially induced slope instability commenced some 31,000 to 34,000 yr ago in Kosciusko area of SE Australia.

Differences in ages of various organic components of samples demonstrate errors which may arise from whole-soil dating. For example, at 
Munyang, originally deposited wood and soil materials apparently have been contaminated by rootlets but not by more recent humus. At Geehi, both humus and rootlet contamination appears to have occurred. Until new methods for treatment of soil materials are developed, it is necessary to select samples where originally comminuted wood or charcoal can be identified and extracted.

\section{B. New Zealand, Volcanics}

Since evolution of the $\mathrm{K} / \mathrm{Ar}$ whole-rock dating technique (Dalrymple, 1963; McDougall, 1964 and 1966) by which radiogenic argon could be detected and measured with good precision in rocks as young as 100,000 $\mathrm{yr}$, it has appeared possible that rocks less than $100,000 \mathrm{yr}$ old could be dated. To evaluate this possibility McDougall et al., (McDougall, I., Stipp, J. J., and Polach, H. A., Excess radiogenic argon in young basalts from the Auckland volcanic field: Acta Geochim. Cosmochim, in press), have undertaken a detailed study of basalts of the Auckland region, New Zealand, where many volcanoes of demonstrably young age existed as shown by geomorphology and stratigraphy (Searle, 1961a) and confirmed by radiocarbon dating carried out on peat and wood buried by eruptions (Fergusson and Rafter, 1959). Indicated K/Ar ages were in marked disagreement with radiocarbon results and the conclusion of study was that excess radiogenic argon is of widespread occurrence in basalts of Auckland region thus placing certain restrictions on use of $\mathrm{K} / \mathrm{Ar}$ method in dating very young volcanic rocks. Samples coll. 1966-67 by J. J. Stipp and 1968 by I. McDougall and H. A. Polach, A.N.U., subm. by Geophysics.

\section{Tamaki River series, Auckland}

McLennan's Hills volcano, $\mathrm{S}$ of Panmure Basin, erupted lavas that flowed mainly $\mathbf{N}$ towards Tamaki $\mathrm{R}$. These lavas are thought by Searle (1961b, 1962) to be younger than tuff that has buried a thick forest, remains of which are now exposed within and below tuff at low tide along bank of river $\left(35^{\circ} 55^{\prime} \mathrm{S}\right.$ Lat, $174^{\circ} 51^{\prime} \mathrm{E}$ Lorig). Because of discrepancy between indicated $\mathrm{C}^{14}$ and $\mathrm{K} / \mathrm{Ar}$ ages, (range 90,000 to 120,000 yr for $\check{5}$ samples), a study of possible contamination of wood samples by younger carbon was undertaken on this sample series. Dated fractions were:

ANU-31.

$26,420 \pm 850$

$$
\Delta=-962.7 \pm 3.7 \quad \delta C^{13}=-23.6 \pm 0.2 \%
$$

Wood, washed, cleaned and examined for intrusive material (shell and rootlets, fungi, and weed growth) and dried without acid wash (described in further text by annotation AS IS). Benzene, $1740 \mathrm{~min}$. count.

ANU-31 S.

$$
\Delta=-969.2 \pm 2.3 \quad \delta C^{13}=-23.7 \pm 0.2 \%
$$

$\mathrm{NaOH}$-soluble fraction of portion of same sample, ca. $10 \%$ of total treated. Benzene, $2440 \mathrm{~min}$. count. 
ANU-31 L.

$28,150 \pm 650$

$$
د=-969.0 \pm 2.3 \quad \delta C^{13}=-25.1 \pm 0.2 \%
$$

Lignin portion of sample, ca. $67 \%$ of total treated. Benzene, 2240 min. count.

ANU-31 I.

$\mathbf{2 7 , 5 1 0} \pm \mathbf{5 0 0}$

$$
د=-967.5 \pm 2.2 \quad \delta C^{13}=-23.1 \pm 0.2 \%
$$
count.

$\mathrm{NaOH}$-insoluble residue, ca. $90 \%$ of total treated. Benzene, $2300 \mathrm{~min}$.

ANU-31 C1.

$26,590 \pm 1150$

$$
\Delta=-963.5 \pm 5.1 \quad \delta C^{13}=-22.2 \pm 0.2 \%
$$

Cellulose portion of sample, ca. $43 \%$ of total treated. Benzene dilution, $1000 \mathrm{~min}$. count.

ANU-31 C2.

$\mathbf{2 5 , 8 4 0} \pm \mathbf{3 3 0}$

$$
د=-959.9 \pm 1.6 \quad \delta C^{13}=-19.8 \pm 0.2 \%
$$

Repeat preparation of cellulose, ca. $43 \%$ of total treated. Benzene, 5000 min. count.

ANU.31 R/1.

$$
\Delta=-965.3 \pm 3.0 \quad \delta C^{13}=-25.0 \pm 0.2 \%
$$

Ethyl acetate soluble resin, ca. $13 \%$ of total treated. Benzene, 1500 min. count.

ANU-31 R/2.

$$
\Delta=-964.5 \pm 3.4 \quad \delta C^{13}=-25.0 \pm 0.2 \%
$$

Repeat combustion and benzene synthesis of ANU-31 $\mathrm{R} / 1$. Benzene dilution, 3320 min. count.

ANU-256.

$26,920 \pm 800$

$$
\Delta=-964.9 \pm 3.5 \quad \text { Est. } \delta C^{13}=-24.0 \pm 2.0 \%
$$

Wood, AS IS. Benzene, 1020 min. count.

ANU-257.

$\mathbf{2 6 , 4 8 0} \pm 800$

$$
\Delta=-963.0 \pm 3.6 \quad \text { Est. } \delta C^{13}=-24.0 \pm 2.0 \%
$$

Wood, AS IS. Benzene 980 min. count.

General Comment (H.A.P.): statistical analysis of distribution of $\Delta$ values show that all may belong to a single, homogeneous population. Therefore there is no evidence of contamination by younger carbon. An errorweighted mean age for this series, i.e., $26,910 \pm 190$ B.P., mean $\delta \mathrm{C}^{13}=$ $-24.0 \pm 0.1$; mean $\Delta=-964.9 \pm 0.8$; benzene, $21,940 \mathrm{~min}$. count, has been calculated as the age that approximates closely time of burial of the forest. The group of ages is also in excellent agreement with NZ-217, $28,000 \pm 1000$ B.P. (Radiocarbon, 1963, v. 5, p. 143).

\section{Maungataketake (Ihumatao) series, Auckland}

This small volcano $\left(37^{\circ} 00^{\prime} \mathrm{S}\right.$ Lat, $174^{\circ} 45^{\prime} \mathrm{E}$ Long), adjacent to Manukau Harbour produced in initial stages much tuff which buried an 
extensive kauri (Agathis Australis) forest (Searle, 1959). Subsequently erupted basalts clearly overlie the tuff stratigraphically. Two reported $\mathrm{C}^{14}$ ages existed, NZ-215, 29,000 \pm 1500 в.P. (Radiocarbon, 1963, v. 5, p. 143) and ANU-9, 31,000 \pm 1000 (Radiocarbon, 1967, v. 9, p. 19). Because of the indicated 100,000 to $126,000 \mathrm{yr}$ for $\mathrm{K} / \mathrm{Ar}$ ages, new samples (ANU-32, ANU-34) were coll. by Stipp, and ANU-36 (part of NZ-215) was obtained from Rafter. As examination subsequent to publication of result on core of ANU-9 revealed presence of soft, flexible, flattened rootlets, chemical separation into component fractions was undertaken in attempt to establish whether contamination by young carbon, other than rootlets, occurred. Also where sample size permitted, larger volumes of benzene were prepared and background counting was done over extended periods both on our Benzene-Old Standard and New Zealand Coal-Old Standard, supplied by Rafter, (Polach, 1969) thereby extending theoretical limit of $\mathrm{C}^{14}$ detection to 52,000 B.P. on our equipment.

ANU-9 W.

$$
\Delta=-991.6 \pm 2.7 \quad \text { Est. } \delta C^{13}=-24.0 \pm 2.0 \%
$$

Outer soft part of ANU-9. Benzene, 2800 min. count on 3.5g.

ANU-9 C.

$43,620 \pm 1400$

$$
\Delta=-995.6 \pm 0.7 \quad \text { Est. } \delta C^{13}=-24.0 \pm 2.0 \%
$$

Cellulose of core of ANU-9, after removal of rootlets. Benzene, 4200 min. count on $13.7 \mathrm{~g}$.

ANU-9 L.

$42,130 \pm 2000$

$$
\Delta=-994.7 \pm 1.3 \quad \text { Est. } \delta C^{13}=-24.0 \pm 2.0 \%
$$

Lignin of core of ANU-9, after removal of rootlets. Benzene, 3780 min. count on $6.8 \mathrm{~g}$.

ANU-32 SW.

$$
\Delta=-996.2 \pm 2.2 \quad \text { Est. } \delta C^{13}=-24.0 \pm 2.0 \%
$$

Soft wood (outer part), AS IS. Benzene, $2700 \mathrm{~min}$. count on 3.5g.

ANU-32 H.

$36,330 \pm 2100$

$$
\Delta=-989.1 \pm 2.7 \quad \text { Est. } \delta C^{13}=-24.0 \pm 2.0 \%
$$

Heart wood (inner part), AS IS. Benzene, $2800 \mathrm{~min}$. count on $3.5 \mathrm{~g}$.

ANU-32 5.

$38,450 \pm 1800$

$$
\Delta=-991.7 \pm 2.7 \quad \delta C^{13}=-25.0 \pm 0.2 \%
$$

$\mathrm{NaOH}$-soluble fraction on portion of total cross section of ANU-21, ca. $2 \%$ of total treated. Benzene, $5400 \mathrm{~min}$. count on $4.3 \mathrm{~g}$.

ANU-32 I.

$40,670 \pm 1800$

$$
\Delta=-993.7 \pm 1.3 \quad \delta C^{13}=-25.0 \pm 0.2 \% 0
$$

$\mathrm{NaOH}$-insoluble residue ca. $96 \%$ of total treated. Benzene, $1840 \mathrm{~min}$. count on $8.8 \mathrm{~g}$. 
ANU-32 CL.

$$
\Delta=-994.6 \pm 1.5 \quad \delta C^{13}=-25.0 \pm 0.2 \%
$$

Cellulose and lignin (water, ethyl acetate and acetone solute and solvent free) ca. $80 \%$ of total treated. Benzene, $1840 \mathrm{~min}$. count on $8.8 \mathrm{~g}$.

ANU-34.

Wood, AS IS. Benzene, 2760 min. count on $3.5 \mathrm{~g}$.

ANU-36.

$$
\Delta=-990.6 \pm 3.9 \quad \delta C^{13}=-24.1 \pm 0.2 \%
$$

Wood, AS IS. Portion of NZ-215 dated by Rafter. Benzene, 1380 min. count on $3.5 \mathrm{~g}$.

General Comment (H.A.P.): spread of indicated ages is from $>33,500$ (ANU-36) to 43,620 \pm 1400 (ANU-9 C) disregarding original ANU-9 and NZ-215 determinations. However, a graph of $\Delta$ values of all fractions and samples within this series shows normal distribution (tested statistically) about an error-weighted mean $\Delta$ value. It is therefore possible that the corresponding mean age of $41,750 \pm 700$ B.P., $\delta \mathrm{C}^{13}$ mean $=$ $-24.9 \pm 0.1 ; \Delta$ mean $=-994.5 \pm 0.5$; benzene, 30,420 min. count, registers time of forest burial. Date, however, should be regarded with caution, because contamination has to be postulated to explain earlier determinations on NZ-215 and ANU-9.

\section{Mt. Wellington series, Auckland}

This volcano $\left(36^{\circ} 53^{\prime} \mathrm{S}\right.$ Lat, $174^{\circ} \mathrm{E}$ Long) immediately $\mathrm{N}$ of Panmure Basin appears to be one of younger volcanoes of Auckland field (Searle, 1964). Tree-fern wood, ANU-35, growing in tuff ring of Panmure volcano, was later buried by ash from Mt. Wellington. Pre-existing date on similar, NZ-387, 9,370 \pm 150 B.P. (Searle, 1965) was confirmed by ANU-35.

ANU-35.

$9,390 \pm 95$

$$
\Delta=-689.2 \pm 3.6 \quad \delta C^{13}=-26.5 \pm 0.2 \%
$$

Tree-fern (Cyathea cf. medullaria) fibres, AS IS. Result is average of 2 independent determinations: ANU-35/1, $\delta \mathrm{C}^{13}=-26.5 \pm 0.2 ; \Delta$ $=-692.9 \pm 6.1$; benzene, $720 \mathrm{~min}$. count; $9480 \pm 160$ в.P. and ANU$35 / 2$, assumed $\delta \mathrm{C}^{13}=-26.5 \pm 1.0 ; \Delta=-687.2 \pm 4.5$; benzene, 1240 min. count; $9330 \pm 110$ B.P. Comment (J.J.S.): date $9000 \pm 160$ (NZ225 , Radiocarbon, 1963 , v. 5, p. 145) was obtained on charcoal enclosed in basalt which dated by $\mathrm{K} / \operatorname{Ar} 81,000 \pm 4000$ в.P. (Ga-3185, McDougall, pers. commun.). Radiocarbon results provide convincing evidence that Mt. Wellington was active less than 10,000 yr ago.

\section{Rangitoto series, Auckland}

Rangitoto, volcanic is. (36 $46^{\prime} \mathrm{S}$ Lat, $174^{\circ} 52^{\prime} \mathrm{E}$ Long) is considered youngest in region, based on geomorphology and botanical evi- 
dence (Millener, 1965) and confirmed by radiocarbon dating of material buried in Rangitoto ash. Shell, $750 \pm 50$ B.P., NZ-220 and carbonized wood $770 \pm 50$, NZ-220 (Radiocarbon, 1963, v. 5, p. 144; Brothers and Golson, 1959).

ANU-258.

$$
225 \pm 110
$$

$$
\Delta=-27.7 \pm 13.0 \quad \text { Est. } \delta C^{13}=-24.0 \pm 2.0 \%
$$

Non-charred wood beneath a young Rangitoto lava flow devoid of vegetation. AS IS. Benzene, $280 \mathrm{~min}$. count. Comment (J.J.S.): $\mathrm{K} / \mathrm{Ar}$ samples from both vegetated and unvegetated lava flows gave age range from 146,000 to $465,000 \mathrm{yr}$. This is the most dramatic example of discordance of $\mathrm{K} / \mathrm{Ar}$ dates in Auckland field with indisputable geologic and $\mathrm{C}^{14}$ dating evidence.

\section{Mt. Wiri (Manurewa) series, Auckland}

Mt. Wiri is middle volcano in group of 3 aligned NE near $S$ boundary of Auckland field. Basalt flows were principal eruptives and during quarrying operations wood buried by eruption was exposed. A previously dated wood sample, NZ-388, 28,300 \pm 690 B.P. (Searle, 1965) came apparently from same locality as ANU-33.

ANU-33.

$$
\Delta=-956.3 \pm 2.8 \quad \delta C^{13}=-21.4 \pm 0.2 \% c
$$

Wood, Mt. Wiri quarry ( $37^{\circ} 00^{\prime} \mathrm{S}$ Lat, $174^{\circ} 51^{\prime} \mathrm{E}$ Long). AS IS. Result is average of 2 independent determinations. ANU-33/1, $\delta \mathrm{C}^{13}=$ $-21.4 \pm 0.2 ; \Delta=-954.2 \pm 2.8$; benzene, $2700 \mathrm{~min}$. count; $24,770 \pm 500$ and $\mathrm{ANU}-33 / 2$, est. $\delta \mathrm{C}^{13}=-21.4 \pm 1.0 ; \Delta=-958.2 \pm 2.7$; benzene, 2780 min. count; $25,510 \pm 550$. Comment (H.A.P.): reason for discrepancy between ANU and NZ date on similar material is not known and sufficient material was not available to carry out component extraction. Comment (J.J.S.): discrepancy between $\mathrm{K} / \mathrm{Ar}$ at ca. $60,000 \mathrm{yr}$ and $\mathrm{C}^{14}$ ages is much less in case of Mt. Wiri than for volcanoes already discussed.

\section{New Guinea, Marine Terraces}

\section{Kalasa series, North Huon Peninsula, New Guinea}

Extensive flight of emerged coral reefs is developed along $\mathrm{N}$ coast region of Huon Peninsula, extending from Masaweng R. $\left(6^{\circ} 24^{\prime} \mathrm{S}\right.$ Lat, $147^{\circ} 48^{\prime} \mathrm{E}$ Long). Terraces, which in places rise to $>+700 \mathrm{~m}$, have developed on $\mathrm{N}$ flank of Huon mts. during tectonic uplift of range; all are presumed Pleistocene in age (Chappell, Quaternary geology of North Huon Peninsula coastal region, New Guinea: ms. in preparation).

Although terraces have risen much faster than flights of terraces customarily correlated with glacio-eustatic sea-level oscillations (Fairbridge, 1962; Chappell, 1968), morphology of terrace flight nevertheless allows for correlation between Pleistocene glacio-eustatic record and particular terrace surfaces of Huon succession. Cross section in Figure 1 indicates that succession is composed of broad benches interspersed with steep flights of narrow shelves. It is postulated that the Peninsula has been 


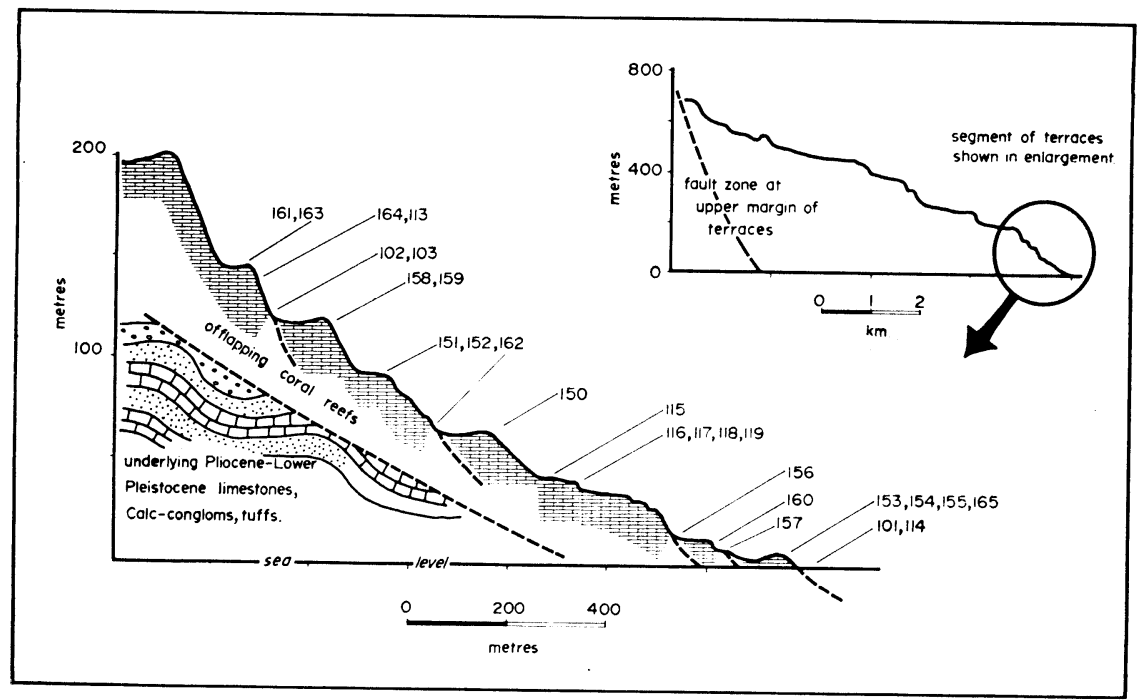

Fig. 1. Structural cross section of lower pair of North Huon terraces, New Guinea. The smaller diagram, upper right, shows the relationship between the terraces within the range of $\mathrm{C}^{14}$ and the total flight of raised coral reefs.

rising more or less continually though not necessarily uniformly during Pleistocene times and therefore steepest flights correspond to glacioeustatic regressions when movements of land and sea have been opposed. Conversely, broad benches have formed during glacio-eustatic transgressions and particularly at times when rising sea overtook uplifting land and allowed barrier reefs to develop. On this basis, the narrow coastal strip of low-lying land and lower parts of first steep flight, encircled in upper right of Figure 1, and enlarged in body of the diagram, may be equivalent in age to later phases of Würm Glaciation.

Each important terrace can be followed in the field for tens of $\mathrm{kms}$, and dated samples reported below are referred to their appropriate surface as shown in Figure 1. Samples are listed in groups according to terrace or origin. All samples are invertebrate carbonate, either of the large clam Tridacna gigas, or of reef corals. Discolored portions of all fossils were removed by sawing, and drilling where necessary, before $\mathrm{HCl}$ digestion. Although majority of fossils dated were almost wholly aragonite, presumed original exoskeletal material, a fair proportion were partly recrystallized to calcite. Both $\Delta$ values, and $\delta \mathrm{C}^{14}$ uncorrected $\delta \mathrm{C}^{13}$ are listed below because of significance for recrystallization studies (Chappell, J. and Polach, H. A., Recrystallization process in late Quaternary corals, in the light of carbon isotope data: $\mathrm{ms}$. in preparation). Ages reported for non-recrystallized specimens are to some extent falsely "old" owing to effect of correcting, relative to $\delta \mathrm{C}^{13}=-25 \%$ for wood, the $\delta \mathrm{C}^{14}$ for marine carbonates which have a natural $\delta \mathrm{C}^{13} \cong 0+2.5$ (cf. Craig, 1954; Polach, 1969). Dating study of terraces is being currently extended by $\mathrm{U} / \mathrm{Th}$ disequilibrium dating by $\mathrm{H}$. Veeh, Dept. of Geo- 
physics and J. Chappell, Dept. of Geography, A.N.U. (work in progress). Samples coll. 1967-68 by J. Chappell and subm. by Dept. of Geophysics.

1) Modern samples

$$
\begin{array}{rrr}
\text { ANU-101. Modern Tridacna, Apparent Age } & \mathbf{5 3 5} \pm \mathbf{4 5} \\
\delta \mathrm{C}^{14}=-10.9 \pm 5.0 & \text { Modern } \\
\Delta=-64.3 \pm 5.0 \quad \delta C^{13}=+2.4 \pm 0.2 \%
\end{array}
$$

Coll. from beach immediately behind narrow fringing reef at Sialum is. (6 $6^{\circ} 07^{\prime} \mathrm{S}$ Lat, $147^{\circ} 36^{\prime} \mathrm{E}$ Long), shell not eroded. Benzene, 2800 min. count.

ANU-114. Modern reef-coral, Apparent Age

$$
\Delta=-33.10 \pm 5.7 \quad \text { Est. } \delta C^{13}=+0.5 \pm 1.0 \% \mathrm{co}
$$

Coll. in situ on reef top, same locality as ANU-101. Benzene, 2520 min. count.

\section{2) Samples from lowest uplifted reef}

All samples coll. from exposures in contemporary sea cliff cut into reef which in places formed nearshore barrier and in other places narrow fringing reef. Reef locally is uplifted as much as $20 \mathrm{~m}$, and is interpreted as becoming emergent immediately after culmination of last phase of Postglacial Transgression.

ANU-153. Tridacna, $+5 \mathbf{m} \delta C^{14}=-546.8 \pm 5.0 \quad \mathbf{6 8 0 0} \pm \mathbf{1 0 0}$

$$
\Delta=-571.4 \pm 5.0 \quad \delta C^{13}=+2.9 \pm 0.2 \%
$$

Coll. in sea cliff $1.5 \mathrm{~km} \mathrm{~W}$ of Sialum $\left(6^{\circ} 07^{\prime} \mathrm{S}\right.$ Lat, $147^{\circ} 36^{\prime} \mathrm{E}$ Long). Benzene, 2720 min. count. Sample $<3 \%$ recrystallized.

$$
\begin{aligned}
\text { ANU-154. Reef-coral, }+5 \mathbf{~ m} & \begin{array}{r}
\mathbf{6 9 2 5} \pm \mathbf{1 1 0} \\
\delta C^{14}=-556.0 \pm 5.6 \quad \delta C^{13}=-1.5 \pm 0.2 \% \\
\Delta=-577.8 \pm 5.6
\end{array}
\end{aligned}
$$

Coll. within $0.5 \mathrm{~m}$ of ANU-153. Benzene, $1780 \mathrm{~min}$. count. Sample $18 \%$ recrystallized.

$$
\begin{array}{rl}
\text { ANU-155. Reef-coral, }+\mathbf{5} \mathbf{~ m} & \mathbf{5 9 0 0} \pm \mathbf{1 0 0} \\
\delta C^{14}=-494.8 \pm 5.9 \quad \delta C^{13}=-0.3 \pm 0.2 \% o \\
\Delta=-520.2 \pm 5.8
\end{array}
$$

Coll. $2 \mathrm{~m}$ laterally from ANU-153. Benzene, $2600 \mathrm{~min}$. count. Sample $20 \%$ recrystallized. Comment (J.C.): sample was in growth position next to ANU-153 and ANU-154. Age discrepancy of $10 \sigma$ is attributed to postdepositional addition of $\mathrm{C}^{14}$ during recrystallization to calcite.

ANU-165. Reef-coral, $+\mathbf{3} \mathbf{~ m ~} \delta C^{14}=-542.9 \pm 3.3 \mathbf{6 7 0 0} \pm \mathbf{6 0}$
$\delta C^{13}=+1.0+0.2^{2} / \mathrm{cos}$

$$
\Delta=-565.8 \pm 3.2 \quad \delta C^{13}=+1.0 \pm 0.2 \%
$$

Coll. in sea cliff at Walingai $\left(6^{\circ} 21^{\prime} \mathrm{S}\right.$ Lat, $147^{\circ} 44^{\prime} \mathrm{E}$ Long). Benzene, 2560 min. count. Sample $<4 \%$ recrystallized. Comment (J.C.): age agrees closely with ANU-153 and ANU-154 which are from same reef 
$40 \mathrm{~km} \mathrm{~W}$. Independent $\mathrm{U} / \mathrm{Th}$ determination yielded $6000 \pm 1000$ в.P. (Veeh, pers. commun.).

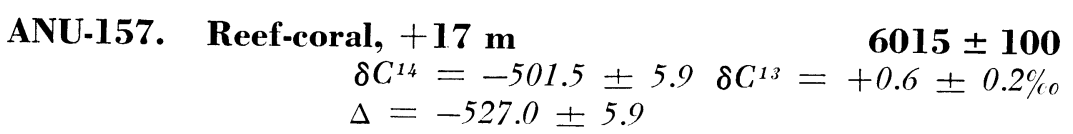

Excavated as loose block within soil profile developed over inland shore of lagoon basin behind lowest raised reef, at Sialum. Benzene, 2340 min. count. Sample 22\% recrystallized. Comment (J.C.): although block may be from higher part of its reef of origin than ANU-153, etc., age difference of 8 sigma is thought to reflect recrystallization.

\section{3) Samples from second reef}

This narrow fringing reef, higher and older than lagoon depression behind lowest reef, supposedly formed during minor standstill in a relative regression of sea level, can be tentatively correlated with earlier phase of regression following last interstadial ( $c f$. Curray, 1961).

ANU-160. Tridacna, $+20 \mathrm{~m} \quad \mathbf{2 8 , 4 7 5} \pm \mathbf{5 7 0}$

$$
\begin{aligned}
& \delta C^{14}=-969.3 \pm 2.1 \quad \delta C^{13}=+3.9 \pm 0.2 \% c \\
& \Delta=-971.1 \pm 2.1
\end{aligned}
$$

Sample $2 \mathrm{~km} \mathrm{E}$ of Sialum. Benzene, $2820 \mathrm{~min}$. count. Sample $<4 \%$ recrystallized. Comment (J.C.): age in agreement with postulated glacioeustatic phase (cf. Curray, 1961).

ANU-156. Tridacna, $+23 \mathrm{~m}$

$$
\delta C^{14}=-972.2 \pm 2.5 \quad \delta C^{13}=+4.3 \pm 0.2 \%
$$$$
\Delta=-973.8 \pm 2.5
$$

Sample from $1.5 \mathrm{~km}$ E of Sialum. Benzene, $2520 \mathrm{~min}$. count. Sample $7 \%$ recrystallized. Comment (J.C.): age agrees with ANU-160, from similar position in same reef.

\section{4) Samples from third reef}

Flight of benches sloping seaward at $10^{\circ}$ lies above $10 \mathrm{~m}$ fossil sea cliff behind 2nd reef, where it occurs at Sialum. Benches inland $200 \mathrm{~m}$ wide pass upward into steeper face of reef breccia facies which terminates upward at crestal barrier and narrow lagoon basin (sample point 150 in Fig. 1). Lower benches are wave cut and reef here is interpreted as forming during marine transgression which culminated with development of lagoon.

$$
\begin{array}{rrr}
\text { ANU.150. Tridacna, }+\mathbf{7 5} \mathbf{~ m} & \mathbf{3 0 , 9 0 0} \pm \mathbf{9 2 0} \\
\delta C^{14}=-977.4 \pm 2.4 & \delta C^{13}=+3.2 \pm 0.2 \% \\
\Delta=-978.6 \pm 2.4 &
\end{array}
$$

Specimen from barrier crest of 3rd reef complex, behind Sialum. Benzene, 2000 min. count. Sample $<4 \%$ recrystallized. Comment (J.C.): reef probably formed at culmination of important marine transgression closely followed by regression, and is postulated as marking the last inter- 
stadial. Determined age agrees well with Curray's (1961) date of this event, determined from submerged shallow-water deposits in Texan Gulf.

ANU-162. Tridacna, $+85 \mathrm{~m}$

$$
\begin{array}{ll}
\delta C^{14}=-982.8 \pm 2.5 & \mathbf{- 1 1 4 0} \\
\Delta=-983.6 \pm 2.5 & \delta C^{13}=+2.4 \pm 0.2 \% 0
\end{array}
$$

Specimen from above small dilapidated fault scarp intersecting inner margin of lagoonal depression at crest of $3 \mathrm{rd}$ reef complex, $2 \mathrm{~km} \mathrm{E}$ of Sialum. Benzene, 2640 min. count. Sample $<4 \%$ recrystallized. Comment (J.C.): sample is upthrown by fault which had become dormant by time of culmination of 3rd reef transgression (dated by ANU-150), it dates late phase of that transgression.

\section{ANU-116. Tridacna, $+42 \mathrm{~m}$}

$$
\begin{array}{ll}
\delta C^{14}=-987.6 \pm 2.1 & \mathbf{- 1 3 5 0} \\
\Delta=-988.3 \pm 2.1 & \delta C^{13}=+2.1 \pm 0.2 \% 0
\end{array}
$$

Specimen from wave cut platform eroded into lower portion of 3rd reef complex, $1.7 \mathrm{~km}$ E of Sialum. Benzene, $4480 \mathrm{~min}$. count. Sample $5 \%$ recrystallized. Comment (J.C.): reef at this point probably formed when sea level was ca. $40 \mathrm{~m}$ lower than its eventual maximum in the last interstadial.

ANU-117. Tridacna, $+42 \mathrm{~m}$

$$
\begin{array}{lr}
\delta C^{14}=-987.0 \pm 1.9 & \mathbf{- 1 2 1 0} \\
\Delta=-987.7 \pm 1.9 & \delta C^{13}=+1.5 \pm 0.2 \%(10
\end{array}
$$

Sample coll. within $5 \mathrm{~m}$ of ANU-116. Benzene, $2940 \mathrm{~min}$. count. Sample 5\% recrystallized. Comment (J.C.): coll. as cross-check on ANU116.

ANU-118. Coral, $+42 \mathrm{~m} \delta C^{14}=-973.6 \pm 2.6 \quad \mathbf{2 9 , 6 0 0} \pm \mathbf{8 3 0}$

$$
\Delta=-974.9 \pm 2.6 \quad \delta C^{13}=-0.6 \pm 0.2 \%
$$

Sample coll. immediately next to ANU-117. Benzene, $3000 \mathrm{~min}$. count. Sample $16 \%$ recrystallized. Comment (J.C.): discrepancy between apparent age of this sample and assumed "reliable" ANU-116 and ANU117 , is attributed to $16 \%$ recrystallization.

ANU-119. Coral, $+42 \mathrm{~m} \delta C^{14}=-884.9 \pm 3.1 \quad \mathbf{1 5 , 4 0 0} \pm \mathbf{1 6 0}$

$$
\Delta=-853.1 \pm 3.0 \quad \delta C^{13}=+0.5 \pm 0.2 \%
$$

Coll. $30 \mathrm{~m}$ horizontally $\mathrm{E}$ of ANU-118. Benzene, $3040 \mathrm{~min}$. count. Sample $51 \%$ recrystallized. Comment (J.C.): sample from same horizon as ANU-116 and ANU-117. Age difference of ca. 20,000 yr. attributable to recrystallization of specimen.

ANU-115. Coral, $+48 \mathrm{~m} \delta C^{14}=-936.7 \pm 3.3 \quad 22,600 \pm 410$

$$
\Delta=-939.9 \pm 3.1 \quad \delta C^{13}=+0.5 \pm 0.2 \%
$$

Coll. $30 \mathrm{~m}$ inland of the group ANU-116 to ANU-119. Benzene, $1660 \mathrm{~min}$. count. Sample $90 \%$ recrystallized. Comment (J.C.): although 
$6 \mathrm{~m}$ higher in the 3rd reef complex than ANU-116, the sample is very much nearer to ANU-116 than to ANU-150 in real age, and should hence be ca. 35,000 B.P. Discrepancy is attributed to extensive recrystallization.

\section{5) Samples from fourth reef}

Similar to 3rd reef complex in general morphology, and ires immediately above and behind it. Contrasting with transgressive nature of 3rd reef, this reef is regressive series of downstepping fringing reefs, although transgressive (barrier reef) complex may exist undeneath these. Samples coll. are therefore related to period of continued emergence of land.

ANU-102. Tridacna $\delta C^{14}=-1001.3 \pm 1.8 \quad$ Background

$$
\Delta=-1001.3 \pm 1.8 \quad \delta C^{1.3}=+2.0 \pm 0.2 \%
$$

Coll. $2 \mathrm{~km} \mathrm{~W}$ of Kelanoa $\left(6^{\circ} 01^{\prime} \mathrm{S}\right.$ Lat, $147^{\circ} 30^{\prime} \mathrm{E}$ Long), $+60 \mathrm{~m}$ at inner margin of broad fringing reef at the top of 4 th reef complex. Benzene, 3900 min. count. Comment (J.C.): sample is from the oldest exposed part of 4th reef complex, representing relative standstill of land and sea.

ANU-103. Tridacna

$$
\begin{aligned}
& \delta C^{14}=-994.9 \pm 1.1 \\
& \Delta=-995.3 \pm 1.1 \quad \delta C^{13}=+3.2 \pm 0.2 \%
\end{aligned}
$$

Coll. near the outer edge of fringing reef at top of 4 th reef complex, result is average of 2 independent determinations: ANU-103/1, est. $\delta \mathrm{C}^{13}=+3.0 \pm 0.4 ; \delta \mathrm{C}^{14}=-991.3 \pm 2.2 ; \Delta=-991.8 \pm 2.2$; benzene, 2700 min. count; ANU-103/2, $\delta \mathrm{C}^{13}=+3.2 \pm 0.2 ; \delta \mathrm{C}^{14}=-996.2 \pm$ 1.3; $\Delta=-996.5 \pm 1.3$; benzene, $2720 \mathrm{~min}$. count on $8.8 \mathrm{~g}$. Sample $<1 \%$ recrystallized. Comment (J.C.): sample represents commencement of $30 \mathrm{~m}$ emergence which followed standstill represented by ANU-102.

$$
\begin{array}{rl}
\text { ANU-158. Tridacna } \delta C^{14}=-960.2 \pm 2.4 & \mathbf{2 6 , 3 8 0} \pm \mathbf{5 1 0} \\
\Delta & =-962.5 \pm 2.4 \quad \delta C^{1.3}=+3.3 \pm 0.2 \%
\end{array}
$$

Coll. above Sialum, within $20 \mathrm{~m}$ of ANU-103 but on outer margin of bench. Benzene, 3000 min. count. Sample $21 \%$ recrystallized. Comment (J.C.): the age discrepancy between this and ANU-103 is attributed to partial recrystallization of ANU-158.

$$
\begin{array}{rrr}
\text { ANU-159. Reef-coral } \delta C^{14}=-868.6 \pm 2.5 & \mathbf{1 6 , 8 0 0} \pm \mathbf{1 6 0} \\
\Delta=-876.3 \pm 2.4 \quad \delta C^{13}=+1.13 \pm 0.2 \%
\end{array}
$$

Coll. adjacent to ANU-158. Benzene, 1240 min. count. Sample $32 \%$ recrystallized. Comment (J.C.): age discrepancy between this and ANU102, ANU-103, is attributed to recrystallization.

$$
\begin{array}{r}
\text { ANU-151. Reef-coral } \delta C^{14}=-747.3 \pm 3.0 \\
\Delta=-760.4 \pm 2.9 \\
\delta C^{13}=+1.30 \pm 0.2 \% c
\end{array}
$$

Sample coll. $1 \mathrm{~km} \mathrm{E}$ of Sialum, $+95 \mathrm{~m}$. Benzene, $2740 \mathrm{~min}$. count. Sample $90 \%$ recrystallized. Comment (J.C.): coral from which sample 
was taken grew during later regressive phase of Reef Complex 4, and therefore is younger than ANU-103 and older than ANU-116, i.e., its true age is $>35,700$. Apparent age, falsely young by at least $24,000 \mathrm{yr}$, is related to recrystallization history.

ANU-152. Reef-coral $\delta C^{14}=-813.4 \pm 3.6 \quad \mathbf{1 3 , 8 9 0} \pm \mathbf{1 6 0}$

$$
\Delta=-822.4 \pm 3.5 \quad \delta C^{13}=+0.6 \pm 0.2 \%
$$

Sample coll. adjacent to ANU-151. Benzene, 1840 min. count. Sample $90 \%$ recrystallized. Comment (J.C.): coll. for recrystallization study the apparent age falsely young by ca. $22,000 \mathrm{yr}$ reflects $90 \%$ of recrystallization.

\section{6) Samples from reefs older than fourth reef complex}

$\delta \mathrm{C}^{14}$ and $\delta \mathrm{C}^{13}$ determinations were made for specimens coll. from higher reefs for 2 purposes: a) to supplement recrystallization study, b) to assess whether unrecrystallized samples known to be much $>50,000$ yr did in fact "date" as beyond range of $\mathrm{C}^{14}$ method.

ANU-111. Tridacna $\delta C^{14}=-998.3 \pm 1.8 \quad$ Background $\Delta=-998.7 \pm 1.7 \quad \delta C^{13}=+2.4 \pm 0.2 \%$

Sample coll. at $+400 \mathrm{~m}, 8 \mathrm{~km}$ directly inland from Kelanoa (at $6^{\circ}$ $03^{\prime} \mathrm{S}$ Lat, $147^{\circ} 28^{\prime} \mathrm{E}$ Long). Benzene, $3980 \mathrm{~min}$. count. Sample $>4 \%$ recrystallized. Comment (J.G.): specimen is from a terrace which is higher than one dated by U/Th at ca. 200,000 B.P. (2 determinations, Veeh, pers. commun.), and was used as system "blank check".

ANU-104. Tridacna $\delta C^{14}=-998.2 \pm 1.1 \quad$ Background

$$
\Delta=-998.3 \pm 1.1 \quad \delta C^{13}=+2.6 \pm 0.2 \%
$$

Sample coll. at $+110 \mathrm{~m}, 3 \mathrm{~km} \mathrm{SW}$ of Kelanoa. Result is average of 2 independent determinations. ANU-104/1, $\delta \mathrm{C}^{13}=+3.2 \pm 0.2 ; \delta \mathrm{C}^{14}$ $=-996.2 \pm 2.2 ; \Delta=-996.4 \pm 2.2$; benzene $2800 \mathrm{~min}$. count, and ANU-104/2, $\delta \mathrm{C}^{13}=+1.9 \pm 0.2 ; \delta \mathrm{C}^{14}=-998.7 \pm 1.2 ; \Delta=-998.8$ \pm 1.2 ; benzene $4000 \mathrm{~min}$. count on $8.8 \mathrm{~g}$. Sample $<1 \%$ recrystallized. Comment (J.C.): presumed of last interglacial age, and mean $\Delta=$ $-998.3 \pm 1.1$ suggests that highly meaningful age determinations can be made for unrecrystallized shells of this type.

$$
\begin{array}{rc}
\text { ANU-107. Tridacna } & \mathbf{3 9 , 1 3 0} \\
\delta C^{14}=-991.9 \pm 1.6 & \mathbf{- 1 5 0 0} \\
\Delta=-992.3 \pm 1.6 & \delta C^{13}=+2.2 \pm 0.2 \%
\end{array}
$$

Sample coll. adjacent to ANU-104. Benzene, $2960 \mathrm{~min}$. count on 7.9g. Sample $5.5 \%$ recrystallized. Comment (J.C.): demonstrates effect of slight partial recrystallization.

ANU-163. Tridacna

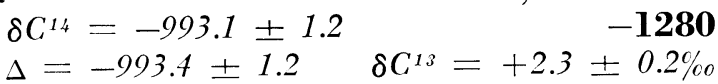

Sample coll. at $+145 \mathrm{~m}$ directly behind Sialum. Result is average of 
2 independent determinations, ANU-163/1, $\delta \mathrm{C}^{13}=+2.4 \pm 0.2 ; \delta \mathrm{C}^{14}$ $=-994.2 \pm 2.3 ; \Delta=-994.5 \pm 2.3$; benzene, $5000 \mathrm{~min}$. count; and ANU-163/2, $\delta \mathrm{C}^{13}=+2.1 \pm 0.2 ; \delta \mathrm{C}^{14}=-992.7 \pm 1.3 ; \Delta=-993.1$ \pm 1.3 ; benzene, $3040 \mathrm{~min}$, count on $8.8 \mathrm{~g}$. Sample $4 \%$ recrystallized. Comment (J.C.): from reef older than the 4 th complex, outside range of $\mathrm{C}^{14}$ dating. Demonstrates effect of slight partial recrystallization.

ANU-161. Reef-coral $\delta C^{14}=-974.6 \pm 2.6 \quad \mathbf{2 9 , 9 3 0} \pm \mathbf{8 7 0}$ $\Delta=-975.9 \pm 2.6 \quad \delta C^{13}=-0.2 \pm 0.2 \%$

Sample coll. adjacent to ANU-163. Benzene, 3000 min. count. Sample $53 \%$ recrystallized. Comment (J.C.): falsely young age reflects recrystallization.

ANU-113. Reef-coral $\delta C^{14}=-975.3 \pm 2.3 \quad \mathbf{3 0 , 1 5 0} \pm \mathbf{8 0 0}$

$$
\Delta=-976.6 \pm 2.3 \quad \text { Est. } \delta C^{13}=0.0 \pm 2.0 \%
$$

Sample coll. at $+135 \mathrm{~m}$ above sea level, directly behind Sialum, at lower level in same reef complex as ANU-161. Benzene, $2500 \mathrm{~min}$. count. Sample 22\% recrystallized. Comment (J.C.): although ANU-161 is twice as extensively recrystallized, age errors of ANU-161 and ANU-113 are similar.

ANU-164. Reef-coral $\delta C^{14}=-709.5 \pm 4.1 \quad \mathbf{1 0 , 3 6 0} \pm \mathbf{1 1 0}$

$$
\Delta=-724.4 \pm 3.9 \quad \delta C^{13}=+0.7 \pm 0.2 \%
$$

Sample coll. within $10 \mathrm{~m}$ of ANU-113. Benzene, $1200 \mathrm{~min}$. count. Sample is $>95 \%$ recrystallized. Comment (J.C.): almost totally recrystallized, apparent age discrepancy is greatest in series.

General Comment (J.C.): almost all recrystallized samples appear falsely young but there is no simple correlation between degree of recrystallization and percentage alteration of $\Delta$. These results are interpreted in terms of models for recrystallization by Chappell and Polach (ms. in preparation).

Date lists:

ANU I

ANU II

Lamont VIII

New Zealand I-V

\section{REFERENCFS}

Broecker, W. S. and Olson, E. A., 1961, Lamont radiocarbon measurements VIII: Radiocarbon, v. 3, p. 176-204.

Brothers, R. N. and Golson, J., 1959, Geological and archaeological interpretation of section in Rangitoto ash on Motutapu Island, Auckland: New Zealand Jour. Geol. and Geophys., v. 2, p. 569-577.

Chappell, J., 1968, Changing duration of glacial cycles from lower to upper Pleistocene: Nature, v. 219 , p. $36-40$.

Craig, Harmon, 1954, Carbon 13 in plants and the relationship between carbon 13 and carbon 14 variations in nature: Jour. Geology, v. 62, no. 2, p. 115-149.

1957 , Isotopic standards for carbon and oxygen and correction factors for mass-spectrometric analysis of carbon dioxide: Geochim. et Cosmochim. Acta, v. 12, p. $133-149$

Curray, J. R., 196I, Late Quaternary sea level: a discussion: Geol. Soc. America Bull., v. 72 , p. $1707-1712$. 
Dalrymple, G. B., 1963, Potassium-argon dates on some cenozoic volcanic rocks of the Sierra Nevada, California: Geol. Soc. America Bull., v. 74, p. 379-390.

Fairbridgc, R. W., 1962, World sea-level and climatic changes, in: Early man and Pleistocene stratigraphy in the circum-Mediterranean regions: Quaternaria, v. 6, p. 111-134.

Fergusson, G. J. and Rafter, T. A., 1959, New Zealand 14C age measurements, 4: New Zealand Jour. Geol. and Geophys., v. 2, p. 208-241.

Grant-Taylor, T. L. and Rafter, T. A., 1963, New Zealand natural radiocarbon measurements I-V: Radiocarbon, v. 5, p. 118-162.

McDougall, Ian, 1964, Potassium-argon ages from lavas of the Hawaiian Islands: Geol. Soc. America Bull., v. 75, p. 107-128.

1966, Precision method of potassium-argon isotopic age determination on young rocks, in: Methods and techniques in geophysics 2: Interscience, p. 219-304.

Millener, L. H., 1965, Forest, scrub and fresh-water communities, in: Science in Auckland, Handbook 11th Sc. Cong., Royal Soc. New Zealand, Auckland, p. 36-48.

Polach, H. A., 1969, Optimization of liquid scintillation radiocarbon age determinations and reporting of ages: Atomic Energy in Australia, v. 12, no. 3, p. 15-23.

Polach, H. A., Golson, J., Lovering, J. F. and Stipp, J. J., 1968, ANU radiocarbon date list II: Radiocarbon, v. 10, p. 179-199.

Polach, H. A., Stipp, J. J., Golson, J., and Lovering, J. F., 1967, ANU radiocarbon date list I: Radiocarbon, v. 9, p. 15-27.

Searle, E. J., 1959, The volcanoes of Ihumatao and Mangere, Auckland: New Zealand Jour. Geol. and Geophys., v. 2, p. 870-888.

1961a, The age of Auckland volcanoes: New Zealand Geog., v. 17, p. 52-63. $1961 \mathrm{~b}$, Volcanoes of the Otahuhu-Manurewa district, Auckland: New Zealand Jour. Geol. and Geophys., v. 4, p. 239-255.

1962, The Volcanoes of Auckland city: New Zealand Jour. Geol. and Geophys., v. 5, p. 193-227.

1964, City of volcanoes: A geology of Auckland, Pauls Book Arcade, Auckland.

1965, Auckland volcanic district: New Zealand Dept. Sci. Indust. Res., ser. 49 , p. $90-103$. 